\title{
Academy of Science of South Africa survey: Responsibility in the life sciences
}

To the Editor: The Academy of Science of South Africa (ASSAf) would like to invite all practising life scientists in research and diagnostic facilities to take part in a nationwide survey. The survey is based on a questionnaire designed by the World Health Organization that has been tailored to meet the needs of the South African life science community.

The survey investigates life scientists' perceptions of:

- excellence in laboratory practice, bioethics and biosafety/biosecurity within institutions

- science policy making

- scientific collaboration.

The results of this survey will provide insight into life science practices as well as offering perceptions and experiences of life scientists on key issues. The data gathered from this survey will contribute towards a multifaceted study that is currently underway to:

- assess the extent to which systems are in place in to ensure high-quality, safe, secure and responsible life science research and diagnostic activities.

- identify manners in which existing systems may be strengthened.

This study will contribute towards efforts to foster excellence within the life sciences and to supporting South African scientific development. ASSAf appeals to all practising life scientists to complete this survey. It takes 10 minutes and is entirely confidential. The survey can be found at https://www.surveymonkey. com/s/ASSAf_survey.

The results of the survey will form a database that will be securely stored at ASSAf and will not be distributed to any third party for commercial gain. As the official national science academy of South Africa, the ASSAf strives to provide evidence-based scientific advice to the South African scientific and policy community. A better understanding of all life science activities undertaken in the country, and the distribution of life science practitioners will be invaluable for fostering scientific excellence in South Africa. Please help make this study a success by completing and circulating this survey as widely as possible.

\section{Louise Bezuidenhout}

Academy of Science of South Africa, Pretoria, South Africa

louiseb@assaf.org.za

\section{Jill Farrant}

Department of Molecular and Cell Biology, University of Cape Town, South Africa

\section{Chandre Gould}

Institute for Security Studies, Pretoria, South Africa 